International Journal of Social Science And Human Research

ISSN(print): 2644-0679, ISSN(online): 2644-0695

Volume 05 Issue 03 March 2022

DOI: 10.47191/ijsshr/v5-i3-05, Impact factor-5.586

Page No: $751-768$

\title{
Improving the Quality of Service through Strengthening Organizational Culture, Interpersonal Communication, Pedagogical Competence and Trust (Empirical Research Using Pathway Analysis and Sitorem in Lecturers Indonesia Defence University)
}

\author{
Haposan Simatupang ${ }^{1}$, Sri Setyaningsih ${ }^{2}$, Dian Wulandari ${ }^{3}$, Muhammad Ikmal Setiadi ${ }^{4}$ \\ 1, 2, 3 Pakuan University, Jalan Pakuan PO Box 452, Bogor - Indonesia \\ ${ }^{4}$ Politeknik Transportasi Darat Indonesia - STTD Bekasi, Jalan Raya Setu No.58, Bekasi, Jawa Barat 17530 - Indonesia
}

\begin{abstract}
Indonesia Defence University as a university that develops one of the new branches of science, defense science, must be able to meet and detect the development of global threats that are happening especially related to defense and security. Defense science emerged about five decades ago, since western countries introduced the concept of managing the defense sector to discuss how to allocate budgets and human resources, utilizing tools such as in the business world for defense purposes. The study sought to claify efforts to measure service quality based on dominant potential factors. Quality of service is assumed to be an important part in improving the quality of education in a convergent approach derived from external factors of a learner. . In this study, the stages of data analysis techniques begin by conducting descriptive statistical analysis, testing analytical prerequisites, and continued with path analysis. Descriptive statistical analysis aims to describe the data of each variable in a single way. The result is to improve the quality of lecturer services at is trust in Indonesia Defence University to be able to produce superior quality graduates.
\end{abstract}

KEYWORDS: Defense, Lecturer, Research, Science, University

\section{INTRODUCTION}

Efforts to direct education to the approach of quality achievement have existed since a decade ago, and in its development to date reached a contradiction of its own. In the period 2008-2010 the world of education is required to be able to collaborate with many parties where further known the concept of University-Business Collaboration (UBC). Pertuze, et al., (2010) explained that UBC plays a role in increasing the success of projects run by a company to touch the $80 \%$ mark with studies on more than 106 projects run by various companies in the world. Furthermore, the three-element conception (The Triple Helix) described by Henry Etzkowitz in 2008 explains that effective collaboration between government, universities, and the business world will have a significant impact on the development of the production needs of new knowledge and technologies needed by the business world due to an official push on government needs and updating the theoretical thinking of the economy that is outdated in universities (Etzkowitz, Etzkowitz, Etzkowitz) 2011).

Hegemony changes in the quality of education that prioritize business and job fulfillment are also experienced in Indonesia. Indonesia promotes the achievement of World Class University (WCU) standards. Through the Regulation of the Ministry of Research, Technology, and Higher Education Number 50 of 2017 on the Strategic Plan of the Ministry of Research, Technology, and Higher Education 2015-2019, the government targets in 2018 there are at least 4 universities that are included in the world's top 500 universities. From this regulation, every university is required to be able to answer these challenges (Prakoso et al., 2021).

Various strategies must be mobilized to be carried out one of which is to improve non-substance factors related to the quality of the university. The Directorate General of Higher Education in 2021 explained that at this time there are 4 universities in Indonesia that have entered the world's top 500 (Universitas Gadja Mada, Universitas Indonesia, Bandung Institute of Technology, and Airlangga University). To achieve this ranking, one of the focus of the Indonesian government at this time is to increase the number of researchers. From data released by the Ministry of Technology Research and Higher Education (Kemenristekdikti, 2018).

"Indonesia only has 550 researchers per million population. While the number of lecturers with S2 and S3 degrees in

Indonesia reached 75 percent. In terms of employment, the number of professors has now reached 5500 people."

This figure is still very far compared to other countries in Asia. India already has a ratio of 1400 per one million inhabitants. While in other Asian countries, such as Japan has 5000 per one million population. South Korea, 5500 per million population, while Israel 
Improving the Quality of Service through Strengthening Organizational Culture, Interpersonal Communication, Pedagogical Competence and Trust (Empirical Research Using Pathway Analysis and Sitorem in Lecturers Indonesia Defence University)

which is the country with the most number of researchers has 6500 researchers per million population.

\section{Comparison of the number of researchers per 1 million people}

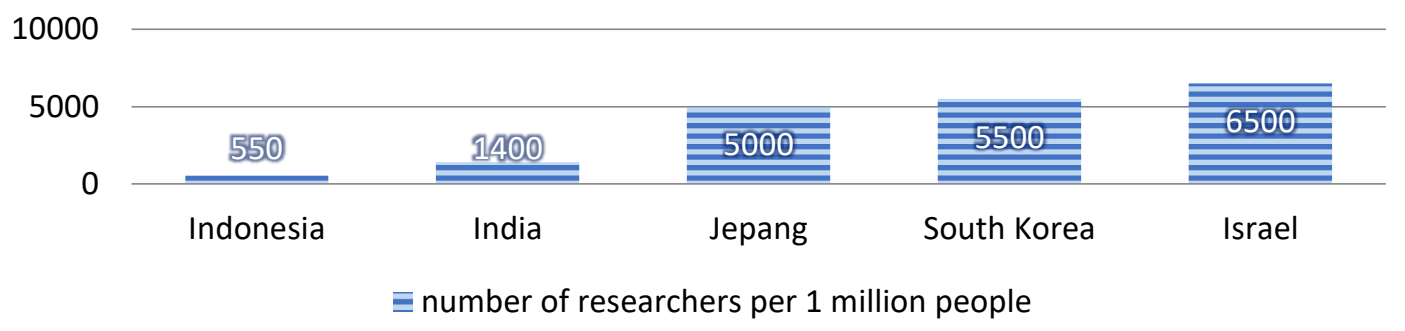

Figure 1. Comparison of The Number of Researchers in Several Countries

Source: lipi.go.id, (2015)

The improvement of the quality of education, furthermore, needs to be questioned directly on the real facts in the social life of the community. Referring to data from the Human Development Index (HDI) issued by the Central Statistics Agency (BPS) in Indonesia, although it has increased since 2010, it is still far from said that education as an effective in building people in Indonesia. BPS 2021 noted that Indonesia's HDI is growing by an average of 0.87 percent per year, but it is specifically understood that Indonesia's HDI is still ranked 107th in the world away from Singapore (11), Brunei Darusalam (47) and Malaysia (62).

HDI indicators such as old school expectations and average length of school still show numbers under 12 years, or still have not achieved higher education above 12 years. Furthermore, indonesia's adjusted per Capita Expenditure (PPP) indicator (Rp. 11.01 Million per year) is still very low when compared to the world average which reaches Rp. 60 Million per year (BPS, 2021; UNDP, 2021). which reaches Rp. 60 Million per year (Badan Pusat Statistik, 2021). This condition has the potential to raise doubts about the education system in Indonesia and even the world as a whole, is it really towards a quality direction to build the nation's civilization? It has been explained earlier that improving the quality of higher education in the world with a standard of both WCU and triple helix education can not be said to be effective, while Indonesia through various policies actually relies on the conception. It should be stated that basically Indonesia has its own characteristic educational philosophy that actually needs to be restored in essence because it contains high noble values (Nizar, A. et al., 2021).

Indonesia through Law No. 12 of 2021 on Higher Education has sought to explain how the essence of an ideal college. In Article 4 of the Act, the College has a function; first, develop the ability and form the character and civilization of a dignified nation in order to educate the life of the nation; Second, develop an innovative, responsive, creative, skilled, competitive, and cooperative Academic Community through the implementation of tridharma; and third, develop Science and Technology by paying attention to and applying humanities values (Prakoso et al, 2021). The noble value of the implementation of universities based on the Law clearly requires intensive attention of various interested parties, especially lecturers. Universities are required to be increasingly professional and selective in managing human resources, especially lecturers as the spearhead of higher education. Lecturers are expected to develop competence and improve their personality, so as to be able to produce an innovation that can be useful for the nation and state (Lukman Yudho Prakoso et al., 2021).

The issue of identity and quality of college services, indicated to occur in the implementation of The Defense University (UNHAN) as a relatively newly established public university, UNHAN is required to be able to fill an important role in creating defense science studies and preparing a cadre of future leaders of Indonesia. UNHAN was established based on Presidential Decree of the Republic of Indonesia Number 5 of 2011 dated February 7, 2011 concerning Defense University as a University Organized by the Government. As a tangible form of civil-military connectedness UNHAN is fostered by two state institutions at once, namely the Ministry of Education and Culture in this case carried out by the Directorate General of Higher Education and functionally fostered by the Ministry of Defense (Suhirwan, Lukman Yudho Prakoso, 2021).

UNHAN provides an opportunity for TNI and civilian officers to learn and deepen Defense Science from a military, political, economic, social and cultural point of view so as to obtain professional relations between civil and military in an academic forum. UNHAN as a university that develops one of the new branches of science, defense science, must be able to meet and detect the development of global threats that are happening especially related to defense and security. Defense science emerged about 5 decades ago, since western countries introduced the concept of managing the defense sector in discussing how to allocate budgets and human resources, by utilizing tools such as in the business world for defense purposes (Supriyatno, 2014).

World Class University hegemony must also be carried out by UNHAN, where UNHAN must be able to adapt to two civilian achievements nuanced education and military achievements of state application character. Through the vision, "By 2024 become a world-class defense university with a research-based that preserves national values." The demands of UNHAN as a world class 


\section{Improving the Quality of Service through Strengthening Organizational Culture, Interpersonal Communication, Pedagogical Competence and Trust (Empirical Research Using Pathway Analysis and Sitorem in Lecturers Indonesia Defence University)}

university must be balanced by various factors related to the quality of service and the development of defense science further to meet the needs of the government in this case the ministry of defense (Lebo et al., 2021).

Trust or trust in the organization has an important role in ensuring sustainability in an organization. Di Fabio (2017) argues that most of an organization's development and growth in both urban and rural contexts is often influenced by trust variables. The study of trust in organizations is inseparable from the spirit and enthusiasm of researchers and scientists in reviewing the relationship between the psychological condition of human resources, connected with organizational management to reveal the role of organizational behavior in predicting the development of an organization in the future (Conchie et al., 2011).

In the implementation of lectures, the quality of lecturer services can be influenced by the leadership style of the Chairman of the Study Program (his superior) (Prihantoro et al., 2021). When the head of the study program can adjust his leadership style to the circumstances of the lecturer and various conditions behind the course of the student study process, then this will greatly support the lecturer in discussing problems with his superiors, lecturers will get effective directions so as to improve the quality of their services. This is in line with the conception of learning organization, where the way organizational learning is based on capabilities is positively influenced by learning organization performance , especially related to knowledge in management, utilization and deepening of a knowledge formed, sustainability of the generation of new ideas and knowledge, application of knowledge, policies, or new routines that are relevant to the context of discarding routines or knowledge. misleading old (Bui \& Baruch, 2010).

Shen and Tang (2018) explained that training indirectly affects the quality of service through training transfer mediation and job satisfaction, so often intensive training becomes the basis for increasing an individual's capacity to provide a service. The teaching process that is part of the teaching service is determined by the motivation of the teaching staff (lecturer), where this motivation consists of two domains: general work motivation, and special teaching motivation (Bjekić et al., 2014). Various variables related to the quality of service as above, but in particular often there are variables that specifically build a quality of service as management in the organization (Prakoso et al., 2021).

\section{LITERATURE REVIEWS}

Organizational behavior in this era of globalization tends to focus on aspects of adaptation, recent studies related to organizational behavior can be found in a study developed by McShane, L. S., and Von Glinow (2018). An integrative model that can be offered in explaining how organizational behavior can be formed is inseparable from balanced input and output patterns. Some variables related to the input and process of organizational behavior form consist of organizational efforts, organizational structure, organizational change, human resource management practices and organizational strategies. Such inputs and processes are described as having a direct impact on individual inputs and processes in the form of individual personalities, values and competencies; selfconcept, perception and mindset of the individual; attitudes and emotions; Motivation, and self-leadership.

In the same input and process is also considered to have an influence on inputs and group processes in the form of tasks, group size and composition; trust, cohesion and group development; communication; leadership; Power, influence and politics; conflict and negotiation of various inputs and processes are also explained that both individual and group processes can influence each other. The three inputs are further inputs and processes for the formation of individuals in the form of performance and behavior; Organizational citizenship behaviour (OCB); well-being, decision and creativity. While group inputs and processes have a direct influence on group results, namely group performance, group decisions, collaboration / mutual support and social networking. In this model individual results and group results are mutually influential. In the final stages individuals and groups have a direct influence on organizational outcomes or organizational effectiveness that can be seen from the conformity of open systems, learning organizations, human capital development, stakeholder satisfaction and organizational ethics. A complete picture of the interrelationship of various factors in the context of organizational behavior.

Organizational behavior is often associated with the psychological condition of employees to the organization, the level of organizational commitment will largely determine how individuals relate to their organization Scales and Quincy Brown (2020). There are many types of relationships between employees and organizations such as effective, normative, and continuity, this linkage is further used as a measure of how committed employees are to the organization that overshadows them Scrima et al. (2015). Effective commitment is the emotional linkage between the individual and the organization; Normative commitment is the employee's feeling to carry out his obligations and responsibilities to the organization; Continuity commitment is a financial factor that individuals get from the organization.

In the relationship of individuals with organizations is also caused by the factors of daily work activities of individuals in the organization, so that the increasing quality of daily work activities will bind individual commitments to the organization and allow individuals to perform other tasks voluntarily (Vallerand, 2015). A person who does not have a commitment to the organization is very likely for the occurrence of withdrawn behavior. The behavior of withdrawing is closely related to the act of refusing to do work in his or her daily duties, the act will essentially allow the individual to resign or leave the organization (Colquitt et al., 2009). 


\section{Improving the Quality of Service through Strengthening Organizational Culture, Interpersonal Communication, Pedagogical Competence and Trust (Empirical Research Using Pathway Analysis and Sitorem in Lecturers Indonesia Defence University)}

\section{METHODS}

Quantitative approaches are considered capable of answering the questions and objectives of the study. Qualitative research that has a positivistic paradigm (Creswell, J, 2008) is considered able to explain the interrelationships between variables used in this study. Quantitative research also aims to take into account objective facts focused on the variables compiled in the research, so that reliability does not need to be questioned again as the study of situational contexts also demands this (Creswell, 2013).

The most popular form of survey design used in education is cross-sectional survey design. In a cross-sectional survey design, researchers collected data at one point in time. This design has the advantage of measuring attitudes or practices that occur at a given time, it also provides information in a short period of time, such as the time it takes to manage surveys and gather information (Creswell, 2013). Surveys are used by first establishing the information needs of the survey, which then the survey can explain three types of information such as descriptive explanations, behaviors, and certain attitudes (Bandur, 2016).

Specifically, this study utilizes path analysis. Pathway analysis is an analysis developed by Sewel Wright in the 1930s, where this analysis is intended to connect and test the causal linkage of conjecture so that it can be accepted in a scientific community (Plausibility), the interrelationship between variables in a study is expected to be observed even though it does not carry out an experimental approach (Vrey, 2012). This method is also believed to analyze the direct or indirect effects of various variables proposed in a hypothesis as a form of treatment of those variables. It should be understood that this analysis is not a cause-andeffect analysis, but rather tends to the causal model applied by research in accordance with the evolving knowledge and conception of a particular theory (Snyder, 1999).

Specifically Alerasoul et al. (2021) explained that path analysis is an application of multireggression studies that use relatively complex and complex path diagrams. As is usually the point of the model, that a consideration is urgently needed. For example considering models involving three variables, such as the relationship between $\mathrm{x}$ and $\mathrm{y}$ or vice versa then the influence of $y$ on $z$, or simultaneously $x$ and $y$ affect $z$, where various correlations of those variables can be linked in a path analysis (Winarsunu, 2006). With the number of variables in this study, path analysis can be the answer to find the connectedness between these variables. Approach the survey method by utilizing the analysis of pathways in research that examines information related to the relationships between variables tested in the study. Free variables consist of, organizational culture (x1), and interpersonal communication (X2), lecturer pedagogical competence (X3), and trust (X4) with quality of service (Y) as bound variables.

\section{A. Population of Research}

In educational survey research, population can be interpreted as a group of individuals who share the same characteristics, the population can be small or large. Thus it is necessary to decide which group to study (Creswell, 2013). However, the population is not only human but can also be objects or objects to be observed (Hadi, 2010). Thus, this study was determined based on the population of lecturers who have been determined based on internal unhan data spread across 12 study programs (study programs), obtained the number of lecturers at UNHAN in 12 study programs as many as 192 people (Arto et al., 2019).

\section{B. Data Collection Techniques}

Data collection techniques are carried out based on established measuring instruments. The data collected can be in the form of numbers, written information, oral information, and various facts related to the focus of the research. Thus the data collection technique in this study, prioritized in two techniques, namely documentation and questionnaire techniques.

The emipiris data to be collected in this study consists of, organizational culture ( $\mathrm{x} 1$ ), and interpersonal communication (x2), lecturer pedagogical abilities (X3), and trust (X4) with quality of service (Y). Furthermore, the picture of data collection can be seen in the following table below.

Table 1. Summary of Data Collection Techniques

\begin{tabular}{|l|l|l|l|l|l|}
\hline Variable & $\begin{array}{l}\text { Measured } \\
\text { Information }\end{array}$ & Respondents & Essence & Scale Type & Answer Options \\
\hline Quality of Service $(\mathrm{Y})$ & Lecturer & Student & Perception & Likert/ Attitide & SA, A, H, D, SD* \\
\hline Organizational Culture $\left(\mathrm{X}_{1}\right)$ & Organization & Lecturer & Perception & Likert/ Attitide & SA, A, H, D, SD* \\
\hline $\begin{array}{l}\text { Intrapersonal } \\
\text { Communication }\left(\mathrm{X}_{2}\right)\end{array}$ & Lecturer & Lecturer & Behaviour & Behaviour & AL, O, SO, E, NE** \\
\hline $\begin{array}{l}\text { Pedagogical } \\
\text { Competence }\left(\mathrm{X}_{3}\right)\end{array}$ & Lecturer & Lecturer & Ability & Test & Correct (1) Wrong (0) \\
\hline Trust $\left(\mathrm{X}_{4}\right)$ & Lecturer & Lecturer & Perception & Likert/ Attitide & SA, A, H, D, SD* \\
\hline
\end{tabular}

* $\mathrm{SA}=$ Strongly Agree, $\mathrm{A}=$ Agree, $\mathrm{H}=$ Hesitate, $\mathrm{D}=$ Disagree, $\mathrm{SD}=$ Strongly Disagree.

$* * \mathrm{~A}=$ Always, $\mathrm{O}=$ Often, $\mathrm{SO}=$ Sometimes, $\mathrm{E}=\mathrm{Ever}, \mathrm{NE}=$ Never. 


\section{Improving the Quality of Service through Strengthening Organizational Culture, Interpersonal Communication, Pedagogical Competence and Trust (Empirical Research Using Pathway Analysis and Sitorem in Lecturers Indonesia Defence University)}

\section{Quality of Service}

The quality of service in this study is measured through student satisfaction with the services provided by lecturers, thus the essence in this variable is perception which is further measured by the Likert scale. Service quality is the conformity between the services provided with the expectations or expectations of those who receive the service. Quality of service is the student's perception of the suitability of services provided by lecturers with their expectations or expectations, measured through questionnaire instruments arranged based on indicators: 1) tangible, 2) reliability, 3) responsibilities, 4) credibility, and 5) empathy (Dipua et al., 2020).

\section{Organizational Culture}

The organizational culture in this study was measured through the lecturer's perception of the organizational culture formed at UNHAN, thus the essence in this variable is perception which is further measured by the Likert scale. Organizational culture is the values, assumptions, norms agreed upon by members as a result of the accumulation of shared learning and adaptation of internal and external changes, which are the reference and direct the behavior of organizational members. The organizational culture in this study is the lecturer's assessment of the values, assumptions, norms agreed with the UNHAN academic community as a result of the accumulation of shared learning and adaptation of internal and external changes, which become a reference and direct the behavior of the UNHAN academic community, measured through questionnaire instruments arranged based on indicators, among others; 1) power distance, 2) uncertainty avoidance, 3) future orientation, 4) institutional collectivism, 5) performance orientation, 6) assertiveness, and 7) humane orientation (Harris et al., 2019).

\section{Intrapersonal Communication}

Interpersonal communication is the exchange of information between two or more people through a familiarity approach so that messages can be received and conveyed by both parties effectively. Interpersonal communication is the lecturer's assessment of his behavior in the exchange of information himself with the academic community of UNHAN through a familiarity approach so that messages can be received and conveyed by both parties effectively, as measured using indicators: a. Active listening, b. Word selection, c. Feedback, d. Empathy, e. Emotional management (Hermawan et al., 2020).

\section{Pedagogical Competence}

Pedagogical competence is the knowledge, proficiency and ability of a teacher in managing a learning system that can help learners or students master the competencies taught. Pedagogical competence is the lecturer's self-assessment of his knowledge, skills and ability to manage a learning system that can help students master the competencies taught, measured using written tests whose problems are arranged based on indicators: 1) the ability to master the characteristics of learners; 2) mastery of learning theories and educational principles; 3) the ability to develop the curriculum; 4) the ability to create educational learning activities; 5) the ability to develop the potential of learners; and 6), assessment and evaluation (Junaidi \& Prakoso, 2021).

\section{Data Analysis techniques and Hypothesis Testing}

In this study, the stages of data analysis techniques begin by conducting descriptive statistical analysis, testing analytical prerequisites, and continued with path analysis. Descriptive statistical analysis aims to describe the data of each variable in a single way. In this study, descriptive statistics included: highest scores, lowest scores, many classes, class intervals, averages, medians, modes, spread sizes or variability using standard deviations and score ranges. In addition, there is also a frequency table and histogram chart (Prasojo et al., 2021).

Inferential statistical analysis aims to test research hypotheses. Hypothesis testing is done using path analysis. In this study hypothesis testing through path analysis describes the effect of free variable (X) on Service Quality as a bound variable (Y). Related to the variables in path analysis, Sugiyono (2016), explains as follows:

(a) Free variables or often referred to as stimulus variables, predictors, antecedents are variables that affect or are the cause of changes or the emergence of dependent variables (bound).

(b) Bound variables or often referred to as output variables, criteria, consequently are variables that are affected or that are consequent, because of the presence of free variables.

The method of path analysis or also called the causal model for directly observed variables. Path analysis is a multivariate data analysis method with the aim of knowing the direct and indirect influence of some exogenous variables (causes) on endogenous variables (consequences) with recursive patterns and all variables can be observed directly. The path analysis model tested in this study is seen in Figure 10 below: 


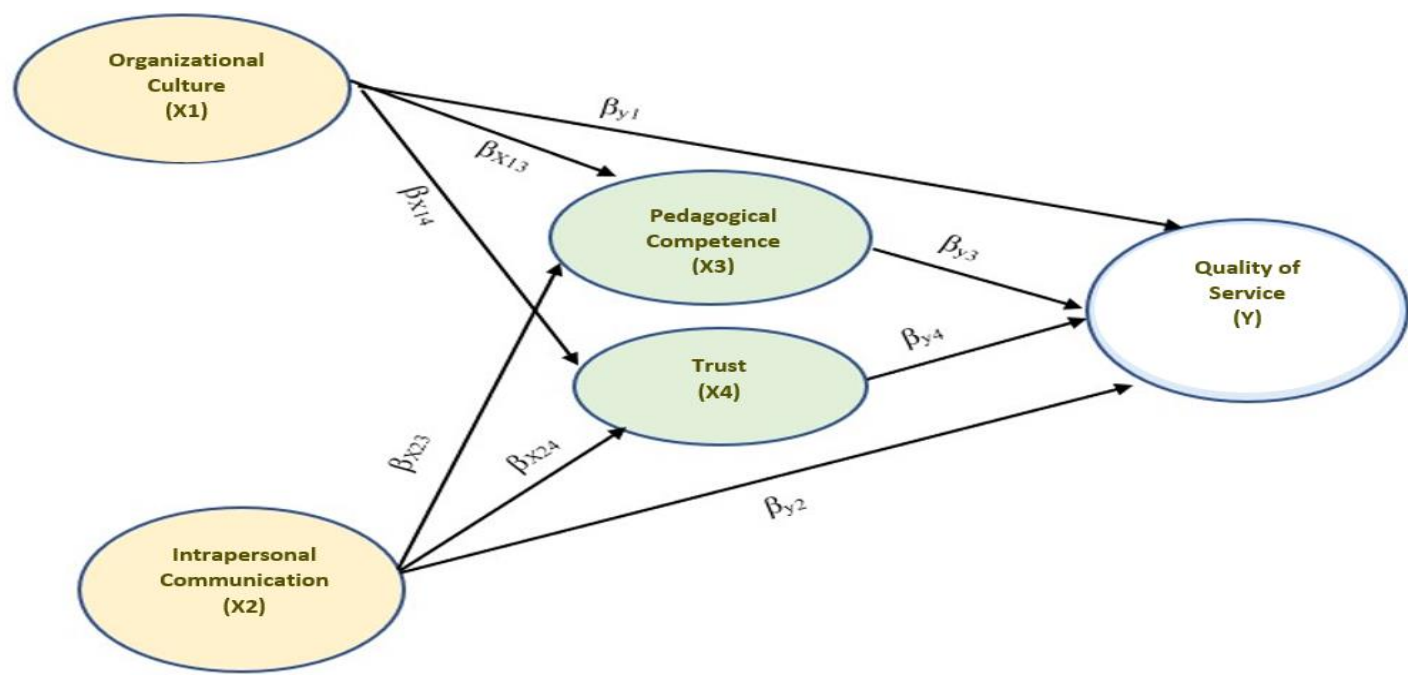

Figure 2. Research Constituency with Path Analysis

Information:

\begin{tabular}{|c|c|c|}
\hline$\beta Y 1$ & $=$ & $\begin{array}{l}\text { Koefisien line pengaruh langsung Organizational Culture (X1) to Quality of Service } \\
\text { (Y). }\end{array}$ \\
\hline$\beta Y 2$ & $=$ & $\begin{array}{l}\text { Koefisien line pengaruh langsung Interpersonal Communication (X2) to Quality of } \\
\text { Service (Y). }\end{array}$ \\
\hline$\beta Y 3$ & $=$ & $\begin{array}{l}\text { Koefisien line pengaruh langsung Pedagogical Competence (X3) to Quality of } \\
\text { Service (Y). }\end{array}$ \\
\hline$\beta Y 4$ & $=$ & Koefisien jalur pengaruh langsung Trust $\left({ }_{\mathrm{X} 4}\right)$ to Quality of Service $(\mathrm{Y})$. \\
\hline$b X 13$ & $=$ & $\begin{array}{l}\text { Koefisien path pengaruh langsung Organizational Culture (X1) to Lecturer } \\
\text { Pedagogical Competence (X3). }\end{array}$ \\
\hline bX14 & $=$ & Koefisien jalur pengaruh langsung Budaya Organisai (X1) against Trust (X4) \\
\hline bX23 & $=$ & $\begin{array}{l}\text { Koefisien path pengaruh langsung Interpersonal Communication (X2) to Lecturer } \\
\text { Pedagogical Competence (X3). }\end{array}$ \\
\hline $\mathrm{X} 24$ & $=$ & pengaruh langsung Interpersonal Communication (X2) to Trust (X4 \\
\hline
\end{tabular}

\section{Statistical Hypothesis Assignment}

In this study there are the following hypotheses:

1. Direct Influence of Organizational Culture ( $\mathrm{x}_{1}$ ) on Quality of Service (Y) но: $\beta$ Y1 $\leq 0$ There is no direct influence of Organizational Culture (X1) on Service Quality (Y) н1: $\beta_{\mathrm{Y} 1}>0$ There is a direct influence of Organizational Culture (X1) on Service Quality (Y)

2. Direct influence of Interpersonal Communication ( $\mathrm{x} 2)$ on Quality of Service $(\mathrm{Y})$. но: $\beta$ Ү2 $\leq 0$ There is no direct influence of Interpersonal Communication (X2) on Service Quality (Y) H1: $\beta$ Y $2>0$ There is a direct influence of Interpersonal Communication (X2) on Service Quality (Y)

3. Direct influence of Pedagogical Competence ( $\left.\mathrm{x}_{3}\right)$ on Service Quality $(\mathrm{Y})$. но: $\beta$ Үз $\leq 0$ There is no direct influence of Lecturer Pedagogical Competence (X3) on Service Quality (Y) H1: $\beta Y 3>0$ There is a direct influence of Lecturer Pedagogical Competence (x3) on Service Quality (Y)

4. $\quad$ Direct influence of Trust $\left(\mathrm{x}_{4}\right)$ on Quality of Service (Y). но: $\beta$ Y4 $\leq 0$ There is no direct influence of Trust (X4) on Service Quality (Y) H1: $\beta Y 4>0$ There is a direct influence of Trust $(\mathrm{x} 4)$ on Service Quality $(\mathrm{Y})$

5. Direct Influence of Organizational Culture ( $\mathrm{x} 1$ ) on Pedagogical Competence (X3). но: $\beta X 13 \leq 0$ There is no direct influence of Organizational Culture (X1) on Lecturer Pedagogical Competence (X3) H1: $\beta$ X13 $>0$ There is a direct influence of Organizational Culture ( $\left.x_{1}\right)$ on Lecturer Pedagogical Competence (X3)

6. Direct influence of Organizational Culture ( $\left.\mathrm{x}_{1}\right)$ on Trust (X4). но: $\beta X 14 \leq 0$ There is no direct influence of Organizational Culture (X1) on Trust (X4) H1: $\beta$ X14 $>0$ There is a direct influence of Organizational Culture (x1) on Trust (X4) 
7. Direct Influence of Interpersonal Communication ( $\left.\mathrm{x}_{2}\right)$ on Lecturer Pedagogical Competence (X3). но: $\beta$ X23 $\leq 0$ There is no direct influence of Interpersonal Communication (X2) on Lecturer Pedagogical Competence (X3)

$\mathrm{H} 1: \beta \mathrm{X} 23>0$ There is a direct influence of Interpersonal Communication $\left(\mathrm{x}_{2}\right)$ on Lecturer Pedagogical Competence (X3)

8. Direct Influence of Interpersonal Communication (x2) on Trust (X4) но: $\beta$ X24 $\leq 0$ There is no influence on Interpersonal Communication (X2) on Trust (X4).

H1: $\beta$ X24 $>0$ There is a direct influence of Interpersonal Communication (X2) on Trust (X4).

\section{RESULT AND DISCUSSION}

In this session tried to explain how the picture of data findings obtained from the research implementation process by measuring variables ranging from the quality of lecturers' services which are bound variables and free variables that are assumed to enrich the quality of lecturer services, namely organizational culture, interpersonal communication, pedagogical competence and trust. At the University of Defense (UNHAN). The data contained in this chapter is obtained based on responses and answers from various respondents who have been designed in the previous chapter (Madrohim, \& Prakoso, 2021).

\section{E. Quality of Service Variable}

Through direct analysis so as to produce primary data, various information about service quality variables are obtained. The variable is described in 33 questionnaire questions through a rating scale of 1 to 5 with a choice of positive statement answers with the provision of Strongly Disagree (STS) with a score of 1, Disapproval (TS) with a score of 2, Doubt (R) with a score of 3, Agree (S) with a score of 4, Strongly Agree (SS) with a score of 5. For negative statements with the following score considerations: Strongly Disagree (STS) with a score of 5, Disagree (TS) with a score of 4, Doubt (R) with a score of 3, Agree (S) with a score of 2, Strongly Agree (SS) with a score of 1 . The statistical description of the respondent's answers can be found in the following table below.

Table 2. Frequency Distribution of Lecturer Service Quality Data (Y)

\begin{tabular}{|l|l|}
\hline Frequency & Quality of Teaching Service (Y) \\
\hline Average & 130,1 \\
\hline Middle Value & 131,5 \\
\hline Mode & 139 \\
\hline Standard Deviation & 20,95 \\
\hline Sample Variant & 439,02 \\
\hline Range & 91 \\
\hline Smallest & 74 \\
\hline Biggest & 165 \\
\hline Lots of data & 100 \\
\hline Sum & 13.010 \\
\hline
\end{tabular}

From the table above it can be understood that descriptive data in the form of mean values has numbers that are close to the mode or can be said to still be in one variant. The distribution of the frequency distribution of the quality of lecturers' services in Unhan can be observed in the following table below.

Table 3. Frequency Distribution of Lecturer Service Quality Data (Y)

\begin{tabular}{|l|l|l|l|}
\hline No & Class intervals & Fabsolut & Relative $(\%)$ \\
\hline 1. & $74-96$ & 8 & 8,00 \\
\hline 2. & $97-119$ & 17 & 17,00 \\
\hline 3. & $120-142$ & 51 & 51,00 \\
\hline 4. & $143-165$ & 24 & 24,00 \\
\hline Total & $\mathbf{1 0 0}$ & $\mathbf{1 0 0 . 0 0}$ \\
\hline
\end{tabular}

Through the table above it can be understood that the frequency distribution with the most frequency scores is in the 3rd class with frelatives of $51.00 \%$ (51 out of 100 respondents) in the range of 120-142. Students who feel the service of lecturers with an average score (130.1) as much as $51 \%$ ( 51 out of 100 students), students who answer the quality of lecturer services above average is $24 \%$ (24 out of 100 students) and answer the quality of lecturer service below the average of $25 \%$ ( 25 out of 100 students). 
Improving the Quality of Service through Strengthening Organizational Culture, Interpersonal Communication, Pedagogical Competence and Trust (Empirical Research Using Pathway Analysis and Sitorem in Lecturers Indonesia Defence University)

The picture shows that the quality of lecturers' services through student answers shows values equal to and above average by $75 \%$, while the quality of lecturer services above average only reaches $24 \%$. To observe the distribution of variable scores of lecturer service quality (Y). From the graph below it can be understood that the frequency distribution of lecturer service quality intervals has a distribution that can be categorized as moderate. This is illustrated by descriptive statistical value data where the most emerging score (mode) is 139 greater than the average with the number 130.10 .

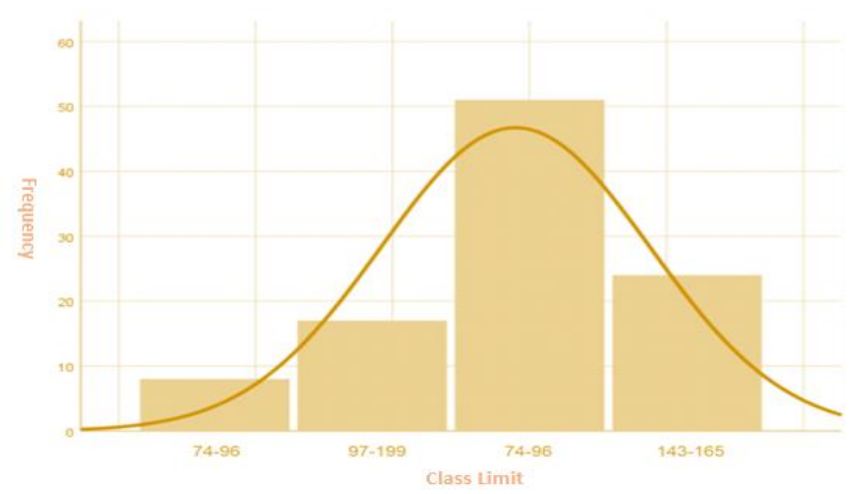

Figure 3. Histogram of Service Quality Data (Y)

\section{F. Organizational Culture Variables ( $x I)$}

Through direct analysis to produce primary data, various information about organizational culture variables $(\mathrm{x} 1)$ are obtained. The variable is described in 34 questionnaire questions through a rating scale of 1 to 5 with a choice of positive statement answers with the provisions strongly disagree (SD) with a score of 1, Disagree (D) with a score of 2, Hesitate (H) with a score of 3, Agree (A) with a score of 4, Strongly Agree (SA). ) with a score of 5. For negative statements with consideration of the following score: Strongly Disagree (SD) with a score of 5, Disagree (D) with a score of 4, Hesitate (H) with a score of 3, Agree (A) with a score of 2, Strongly Agree (SA) ) with a score of 1 . The statistical description of the respondent's answers can be found in the following table below.

Table 4. Frequency Distribution of Organizational Culture Data (X1)

\begin{tabular}{|l|l|}
\hline Frequency & Organizational Culture $\mathbf{( x 1 )}$ \\
\hline Average & 131,1 \\
\hline Middle Value & 134 \\
\hline Mode & 70 \\
\hline Standard Deviation & 28,86 \\
\hline Sample Variant & 832,74 \\
\hline Range & 100 \\
\hline Smallest & 70 \\
\hline Biggest & 170 \\
\hline Lots of data & 100 \\
\hline Sum & 13.110 \\
\hline
\end{tabular}

From the table above it can be understood that descriptive data in the form of mean values has numbers that are close to the mode or can be said to still be in one variant. The picture of the frequency distribution of organizational culture in Unhan can be observed in the following table below.

Table 5. Frequency Distribution of Organizational Culture Data (X1)

\begin{tabular}{|l|l|l|l|}
\hline No & Class intervals & Fabsolut & Relative (\%) \\
\hline 1. & $70-90$ & 12 & 12 \\
\hline 2. & $91-111$ & 11 & 11 \\
\hline 3. & $112-132$ & 13 & 13 \\
\hline 4. & $133-153$ & 37 & 37 \\
\hline 5. & $154-174$ & 27 & 27 \\
\hline \multicolumn{2}{|l|}{ Total } & $\mathbf{1 0 0}$ & $\mathbf{1 0 0 . 0 0}$ \\
\hline
\end{tabular}


Improving the Quality of Service through Strengthening Organizational Culture, Interpersonal Communication, Pedagogical Competence and Trust (Empirical Research Using Pathway Analysis and Sitorem in Lecturers Indonesia Defence University)

Through the table above it can be understood that the distribution of frequencies with the most frequency scores is in the 4th class with frelatives of 37\% (37 out of 100 lecturers) in the range of 133-153. Lecturers who feel organizational culture with an average score (131.1) as much as 13\% (13 out of 100 Lecturers), lecturers who answer the organizational culture above average is $64 \%$ (64 out of 100 lecturers) and answer organizational culture below the average of $23 \%$ ( 23 out of 100 lecturers). The picture shows that the organizational culture figures through question answers show values equal to and below the average of $36 \%$, while the pedagogical ability of lecturers above average reaches $64 \%$. To observe the distribution of the score of the organizational culture variable (X1) is presented in the form of a histogram as follows in the figure below.

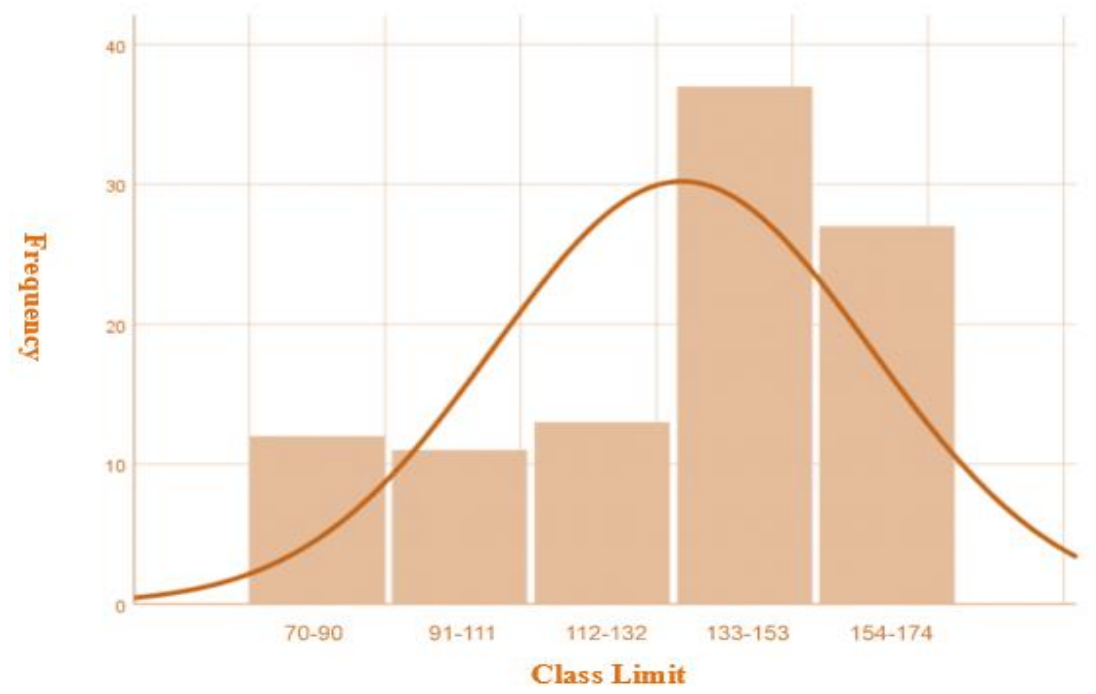

Figure 4. Histogram of Organizational Culture Data (X1)

From the graph above it can be understood that the distribution of frequency intervals of organizational culture has a distribution that can be categorized as high. However, the statistical descriptive value of the data where the most score appears (mode) is 70 smaller than the average with the number 131.1. It is known that the number of questionnaire items is 34 questions in the valid category. From the score it is understood that the lowest theoretical score is 34 and the highest is 170, where the theoretical median is known to be at 102. The lowest empirical score score is 70 and the highest is 170 , with the empirical median being 134 . It can be explained that the empirical median value is above the theoretical median (134>102), thus explaining that the organizational culture in the study can relatively be said to be above the high category.

\section{G. Interpersonal Communication Variables ( $x 2)$}

Through direct analysis to produce primary data, various information about interpersonal communication variables ( $\mathrm{x} 2)$ is obtained. The variable is described in 36 questionnaire questions through a behavioral scale with a rating of 1 to 5 with a choice of positive statement answers with the provision of Never $(\mathrm{Ne})$ with a score of 1, Ever (E) with a score of 2, Sometimes (So) with a score of 3 , Often (O) with a score of 4, Very Often (VO). ) with a score of 5. For negative statements with consideration of the following score: Never (Ne) with a score of 5, Ever (E) with a score of 4, Sometimes (So) with a score of 3, Very Often (VO) with a score of 2, Very Often (VO) ) with a score of 1 . The statistical description of the respondent's answers can be found in the following table below.

Table 6. Frequency Distribution of Interpersonal Communication Data (X2)

\begin{tabular}{|l|l|}
\hline Frequency & Interpersonal Communication (x2) \\
\hline Average & 150,11 \\
\hline Middle Value & $\mathbf{1 4 9 , 5}$ \\
\hline Mode & 140 \\
\hline Standard Deviation & 16,25 \\
\hline Sample Variant & 264,12 \\
\hline Range & 74 \\
\hline Smallest & 106 \\
\hline Biggest & 180 \\
\hline Lots of data & 100 \\
\hline Sum & 15.011 \\
\hline
\end{tabular}


Improving the Quality of Service through Strengthening Organizational Culture, Interpersonal Communication, Pedagogical Competence and Trust (Empirical Research Using Pathway Analysis and Sitorem in Lecturers Indonesia Defence University)

From the table above it can be understood that descriptive data in the form of mean values has numbers that are close to the mode or can be said to still be in one variant. The picture of the frequency distribution of Interpersonal Communication in Unhan can be observed in the following table below.

Table 7. Frequency Distribution of Interpersonal Communication Data (X2)

\begin{tabular}{|l|l|l|l|}
\hline No & Class intervals & Fabsolut & Relative $(\%)$ \\
\hline 1. & $106-120$ & 5 & 5 \\
\hline 2. & $121-135$ & 7 & 7 \\
\hline 3. & $136-150$ & 41 & 41 \\
\hline 4. & $151-165$ & 27 & 27 \\
\hline 5. & $166-180$ & 20 & 20 \\
\hline \multicolumn{2}{|l}{ Total } & $\mathbf{1 0 0}$ & $\mathbf{1 0 0 . 0 0}$ \\
\hline
\end{tabular}

Through the table above it can be understood that the frequency distribution with the most frequency scores is in the 3rd class with frelatives of $41 \%$ ( 41 out of 100 lecturers) in the range of 136-150. Lecturers who feel they have interpersonal communication with an average score (150.11) of $41 \%$ ( 41 out of 100 lecturers), lecturers who answer interpersonal communication above average is $47 \%$ (47 out of 100 lecturers) and answers interpersonal communication below the average of $12 \%$ (12 out of 100 lecturers). The picture shows that interpersonal communication numbers through question answers show values equal to and below the average of 53\%, while interpersonal communication above average only reached $47 \%$. To observe the distribution of the score of the interpersonal communication variable (X2) is presented in the form of a histogram as follows in the figure below.

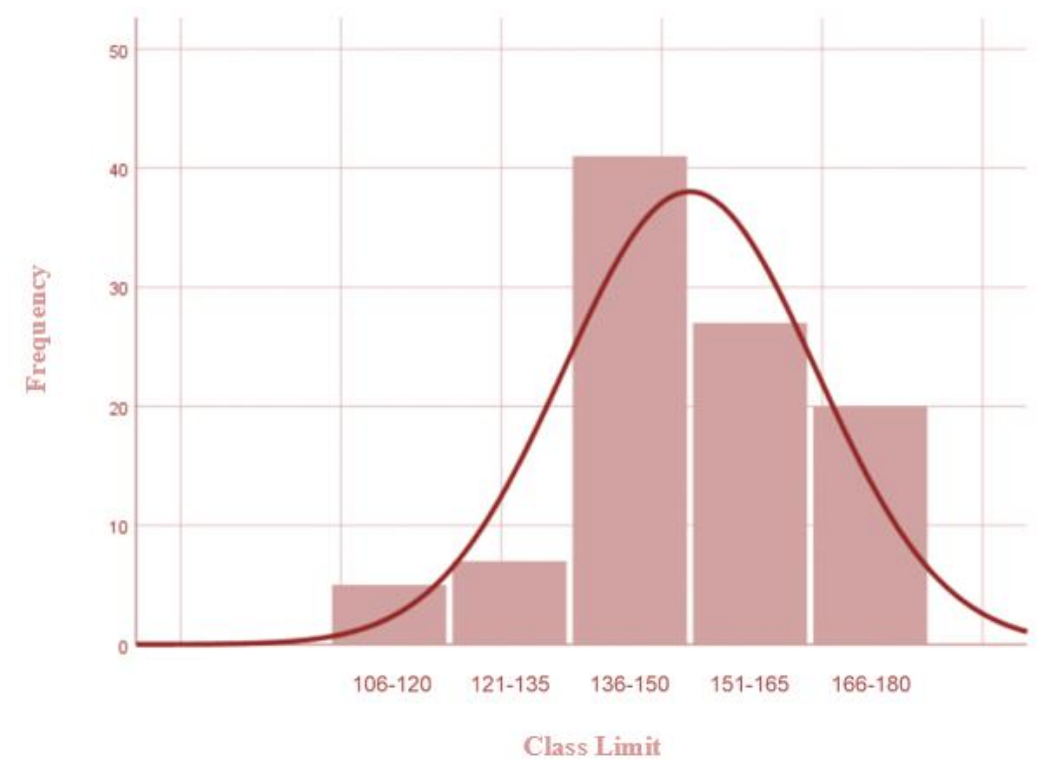

Figure 5. Histogram of Interpersonal Communication Data (X2)

From the graph above it can be understood that the frequency distribution of interpersonal communication intervals has a distribution that can be categorized as high (Arief et al., 2021). However, the statistical descriptive value of the data with the most emerging score (mode) is 140 smaller than the average with the number 150.11. From the previous chapter it is known that the number of questionnaires is 36 questions in 36 and the highest is 180 , where the theoretical median is known to be at 108 . The lowest empirical score score is 106 and the highest is 180, with the empirical median being 149.5. It can be explained that the empirical median value is above the theoretical median (149.5>108), thus explaining that interpersonal communication in this study can relatively be said to be above the high category.

\section{H. Pedagogical Competency Empowerment Variables $(х 3)$}

Through direct analysis so as to produce primary data, various information about pedagogical competency variables ( $\left.\mathrm{x}_{3}\right)$ are obtained. The variable is described in 32 questions through a test with a scoring scale of 1 for the correct answer and 0 for the wrong answer. The statistical description of the respondent's answers can be found in the following table below. 
Improving the Quality of Service through Strengthening Organizational Culture, Interpersonal Communication, Pedagogical Competence and Trust (Empirical Research Using Pathway Analysis and Sitorem in Lecturers Indonesia Defence University)

Table 8. Frequency Distribution of Pedagogical Competency Data (X3)

\begin{tabular}{|l|l|}
\hline Frequency & Pedagogical Competence $\mathbf{( x 3})$ \\
\hline Average & 15,4 \\
\hline Middle Value & 13 \\
\hline Mode & 9 \\
\hline Standard Deviation & 7,39 \\
\hline Sample Variant & 54,67 \\
\hline Range & 26 \\
\hline Smallest & 5 \\
\hline Biggest & 31 \\
\hline Lots of data & 100 \\
\hline Sum & 1.540 \\
\hline
\end{tabular}

From the table above it can be understood that descriptive data in the form of mean values has numbers that are far from the mode numbers or can be said to differ in one variant. The distribution of pedagogical competency frequency (X3) in Unhan can be observed in the following table below.

Table 9. Frequency Distribution of Pedagogical Competency Data (X3)

\begin{tabular}{|l|l|l|l|}
\hline No & Class intervals & Fabsolut & Relative (\%) \\
\hline 1. & $5-8$ & 13 & 13 \\
\hline 2. & $9-12$ & 35 & 35 \\
\hline 3. & $13-16$ & 18 & 18 \\
\hline 4. & $17-20$ & 8 & 8 \\
\hline 5. & $21-24$ & 10 & 10 \\
\hline 6. & $25-28$ & 8 & 8 \\
\hline 7. & $29-32$ & 8 & 8 \\
\hline \multicolumn{2}{|l|}{ Total } & $\mathbf{1 0 0}$ & $\mathbf{1 0 0 . 0 0}$ \\
\hline
\end{tabular}

Through the table above it can be understood that the frequency distribution with the most frequency scores is in the 2nd class with frelatives of 35\% (35 out of 100 lecturers) in the range of 9-12 numbers is also below the average value interval (15.4). Lecturers who have pedagogical competence (X3) with a score below or equal to the average (15.4) of $66 \%$ (66 out of 100 Lecturers), lecturers who answer the question of pedagogical competence above average is $34 \%$ (34 out of 100 lecturers). The figure shows that the pedagogical competency figure (X3) of lecturers through question answers shows values equal to and below the average of $48 \%$, while pedagogical competence $\left(\mathrm{x}_{3}\right)$ lecturers above average only reached $34 \%$. To observe the distribution of the score of the pedagogical competency variable (X3) is presented in the form of a histogram as follows in the figure below.

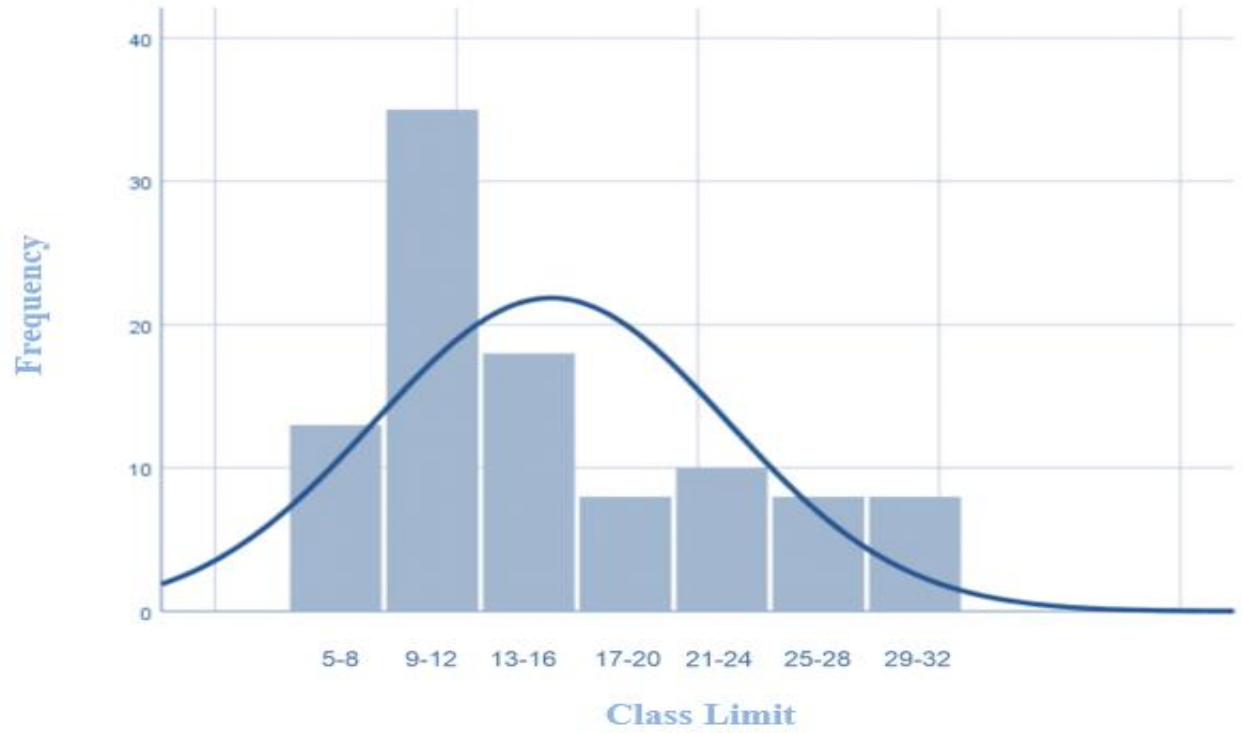

Figure 6. Histogram Pedagogical Competency Data (X3) 

Defence University)

From the graph above it can be understood that the frequency distribution of lecturer pedagogical competency intervals has a distribution that can be categorized as low. This is illustrated by descriptive statistical value data where the most emerging score (mode) is 9 smaller than the average with the number 15.4. It is known that the number of questionnaire items is 32 questions in the valid category. From the score it is understood that the lowest theoretical score is 0 and the highest is 32 , where the theoretical median is known to be at 16 . The lowest empirical score score is 5 and the highest is 31 with the empirical median being 13 . It can be explained that the empirical median value is at a score below the theoretical median $(15.4<16)$, thus explaining that the pedagogical competence $\left(\mathrm{x}_{3}\right)$ in this study can relatively be said to be under the moderate category.

\section{I. $\quad$ Variable Trust (X4)}

Through direct analysis to produce primary data, various information about trust variables (X4) is obtained. The variable is described in 38 questionnaire questions through a rating scale of 1 to 5 with a choice of positive statement answers with the provision of Strongly Disagree (STS) with a score of 1, Disapproval (TS) with a score of 2, Doubt (R) with a score of 3, Agree (S) with a score of 4, Strongly Agree (SS) with a score of 5. For negative statements with the following score considerations: Strongly Disagree (STS) with a score of 5, Disagree (TS) with a score of 4, Doubt (R) with a score of 3, Agree (S) with a score of 2, Strongly Agree (SS) with a score of 1 . The statistical description of the respondent's answers can be found in the following table below.

Table 10. Data Trust Frequency Distribution (X4)

\begin{tabular}{|l|l|}
\hline Frequency & Trust $\left(\mathbf{X}_{\mathbf{4}}\right)$ \\
\hline Average & 157,88 \\
\hline Middle Value & 163,5 \\
\hline Mode & 190 \\
\hline Standard Deviation & 30,57 \\
\hline Sample Variant & 934,35 \\
\hline Range & 150 \\
\hline Smallest & 40 \\
\hline Biggest & 190 \\
\hline Lots of data & 100 \\
\hline Sum & 15.788 \\
\hline
\end{tabular}

From the table above it can be understood that descriptive data in the form of mean values has numbers that are far from the mode or can be said to be different variants. The trust frequency distribution ( $\mathrm{x} 4$ ) picture in Unhan can be observed in the following table below.

Table 11. Data Trust Frequency Distribution (X4)

\begin{tabular}{|l|l|l|l|}
\hline No & Class intervals & Fabsolut & Relative (\%) \\
\hline 1. & $40-65$ & 1 & 1 \\
\hline 2. & $66-91$ & 4 & 4 \\
\hline 3. & $92-117$ & 4 & 4 \\
\hline 4. & $118-143$ & 13 & 13 \\
\hline 5. & $144-169$ & 34 & 34 \\
\hline 6. & $170-195$ & 44 & 44 \\
\hline \multicolumn{2}{|l|}{ Total } & $\mathbf{1 0 0}$ & $\mathbf{1 0 0 . 0 0}$ \\
\hline
\end{tabular}

Through the table above it can be understood that the distribution of frequencies with the most frequency scores is in the 6th class with frelatives of $44 \%$ (44 out of 100 lecturers) in the range of 170-195. Lecturers who feel they have a Trust with an average score (157.88) of $34 \%$ (34 out of 100 Lecturers), lecturers who answer trust above average is $44 \%$ (44 out of 100 lecturers) and ans wer trust below average by $22 \%$ ( 22 out of 100 lecturers). The figure shows that the Trust's figures through question answers show values equal to and below the average of $56 \%$, while trusts above average only reach $44 \%$. To observe the distribution of the trust variable score $(\mathrm{X} 4)$ is presented in the form of a histogram as follows in the figure below. 


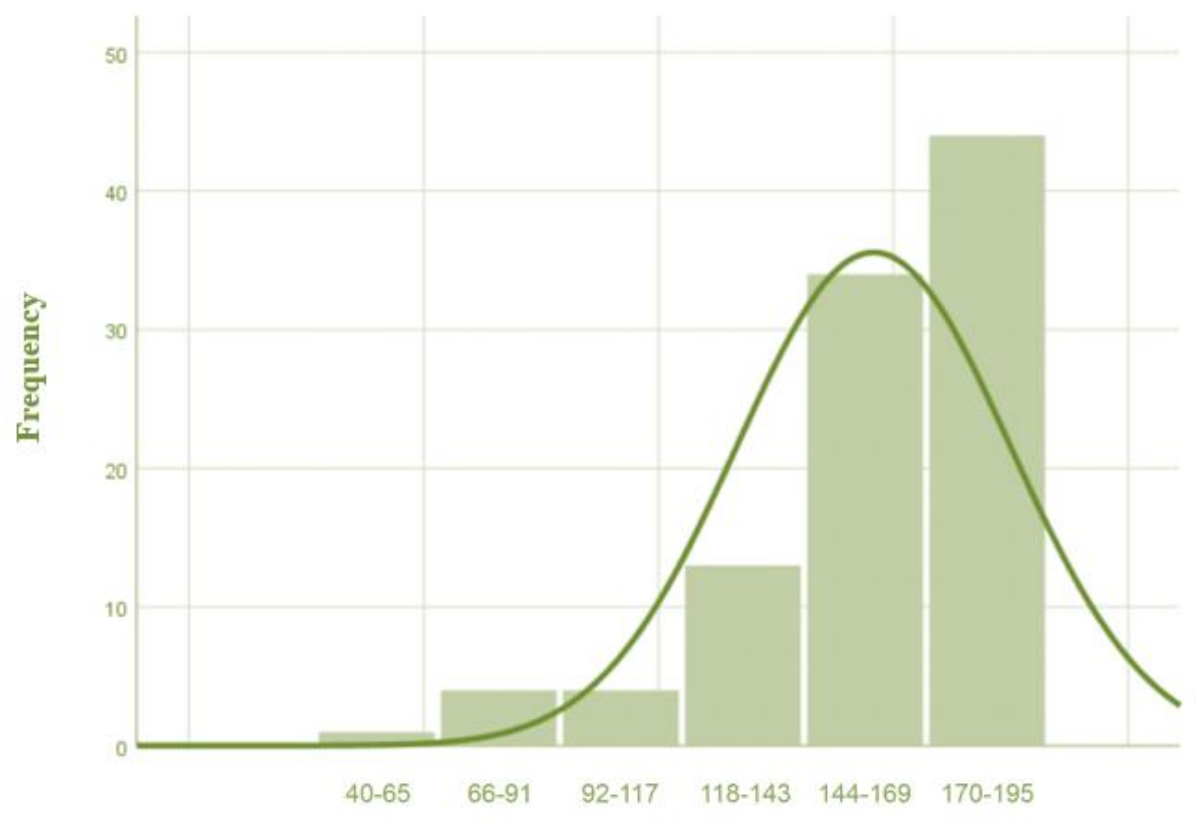

Class Limit

Figure 7. Histogram Trust $\left(\mathrm{X}_{4}\right)$

From the graph above it can be understood that the Trust interval frequency distribution has a spread that can be categorized as high. However, the statistical descriptive value of the data with the most emerging score (mode) is 190 greater than the average with the number 157.88. From the previous chapter it is known that the number of questionnaires is 38 questions in 38 and the highest is 190, where the theoretical median is known to be at 115 . The lowest empirical score score is 40 and the highest is 190 , with the empirical median being 163.5. It can be explained that the empirical median value is above the theoretical median (163.5>115), thus explaining that the Trust in this study can relatively be said to be above the high category (Salim et al., 2020).

\section{J. Summary of Statistical Description of Research Variables}

Based on the results of the analysis of statistical data descriptions for the five previously established variables where the variables are bound is Quality of Service (Y), the free variables are Organizational Culture (x1), Interpersonal Communication (X2), Pedagogical Competence ( $\mathrm{x}_{3}$ ) and Trust (X4). From various analysis of the description of research variables that have been built, can be summarized in the following table below.

Table 12. Summary of Statistical Data Description

\begin{tabular}{|l|l|l|l|l|l|}
\hline Frequency & And & $\mathbf{X}_{\mathbf{1}}$ & $\mathbf{X}_{\mathbf{2}}$ & $\mathbf{X}_{\mathbf{3}}$ & $\mathbf{X}_{\mathbf{4}}$ \\
\hline Average & 130,1 & 131,1 & 150,11 & 15,4 & 157,88 \\
\hline Middle Value & 131,5 & 134 & 149,5 & 13 & 163,5 \\
\hline Mode & 139 & 70 & 140 & 9 & 190 \\
\hline Standard Deviation & 20,95 & 28,86 & 16,25 & 7,39 & 30,57 \\
\hline Sample Variant & 439,02 & 832,74 & 264,12 & 54,67 & 934,35 \\
\hline Range & 91 & 100 & 74 & 26 & 150 \\
\hline Smallest & 74 & 70 & 106 & 5 & 40 \\
\hline Biggest & 165 & 170 & 180 & 31 & 190 \\
\hline Lots of data & 100 & 100 & 100 & 100 & 100 \\
\hline Sum & 13.010 & 13.110 & 15.011 & 1.540 & 15.788 \\
\hline Number of classes & 4 & 5 & 5 & 7 & 6 \\
\hline Class Spacing & 22 & 20 & 14 & 3 & 25 \\
\hline
\end{tabular}

From the various quantitative analyses above it can be understood that there is a close relationship between the various variables tested. However, those relationships when analyzed separately did not show strong positive relationships. The relationship can also 
Improving the Quality of Service through Strengthening Organizational Culture, Interpersonal Communication, Pedagogical Competence and Trust (Empirical Research Using Pathway Analysis and Sitorem in Lecturers Indonesia Defence University)

broadly explain that the quality of service can be formed when there is a process of working the function of organizational culture, interpersonal communication, pedagogical competence, and organizational confidence but not in its entirety and as a whole and simultaneously (Sartono et al., 2020). It should be emphasized that in this study, the development of service quality was only influenced by the correct prediction rate of $14.1 \%$ by variable trust while the rest was influenced by other factors that were not measured in this study. Furthermore, when controlling organizational cultural variables and interpersonal communication can improve the Trust's relationship with service quality, they are predicted at $30.7 \%$ and $33.2 \%$ respectively. The whole discussion of the connectedness of service quality at The Defense University (Unhan) felt by Unhan students based on organizational culture variables, interpersonal communication, pedagogical competence and Trust felt by Unhan lecturers can be seen in the following description below (Manik et al., 2019).

The quality of education in the flow of convergence is closely related to the influence of factors beyond the internal natural abilities of a learner. The quality of education is closely related to efforts to help a learner to be able to develop good potential and prevent the development of bad potential (Stern). A lecturer in this sense will give meaning as a student's assistant who is closely related to the efforts to provide services. Indirectly it can be emphasized that the quality of education is very related to how lecturers provide services to students to be able to optimize their abilities in positive connotations (Narindra et al., 2021).

This research basically limits various factors beyond improving the quality of education through quality of service, but indirectly other factors in efforts to improve the quality of education become an important topic in this study. Some factors such as only institutional support become an integral part in building organizational culture, interpersonal communication, pedagogical competence and trust building efforts. Factors that are not directly measured are also an important part in explaining the quality of service as a whole (Kusuma et al., 2019).

In this study, the close relationship between the main free variable and the bound variable, however, the strong relationship cannot be said to be high enough, the four variables in this study together only affect about $34 \%$ of the quality of service variants. The percentage amount can be said to be below average so it has not significantly changed efforts to improve the quality of service. Partially two endogenous variables (Pedagogical Competence and Trust) exert a not-so-high influence on independent variables which affect above $12.5 \%$ in the effort to variance the quality of service in Unhan, while exogenous variables (organizational culture and interpersonal communication) directly have an influence of $21.5 \%$. The picture of the connectedness between these variables that have also been confirmed through the SITOREM approach can be observed in the following image below:

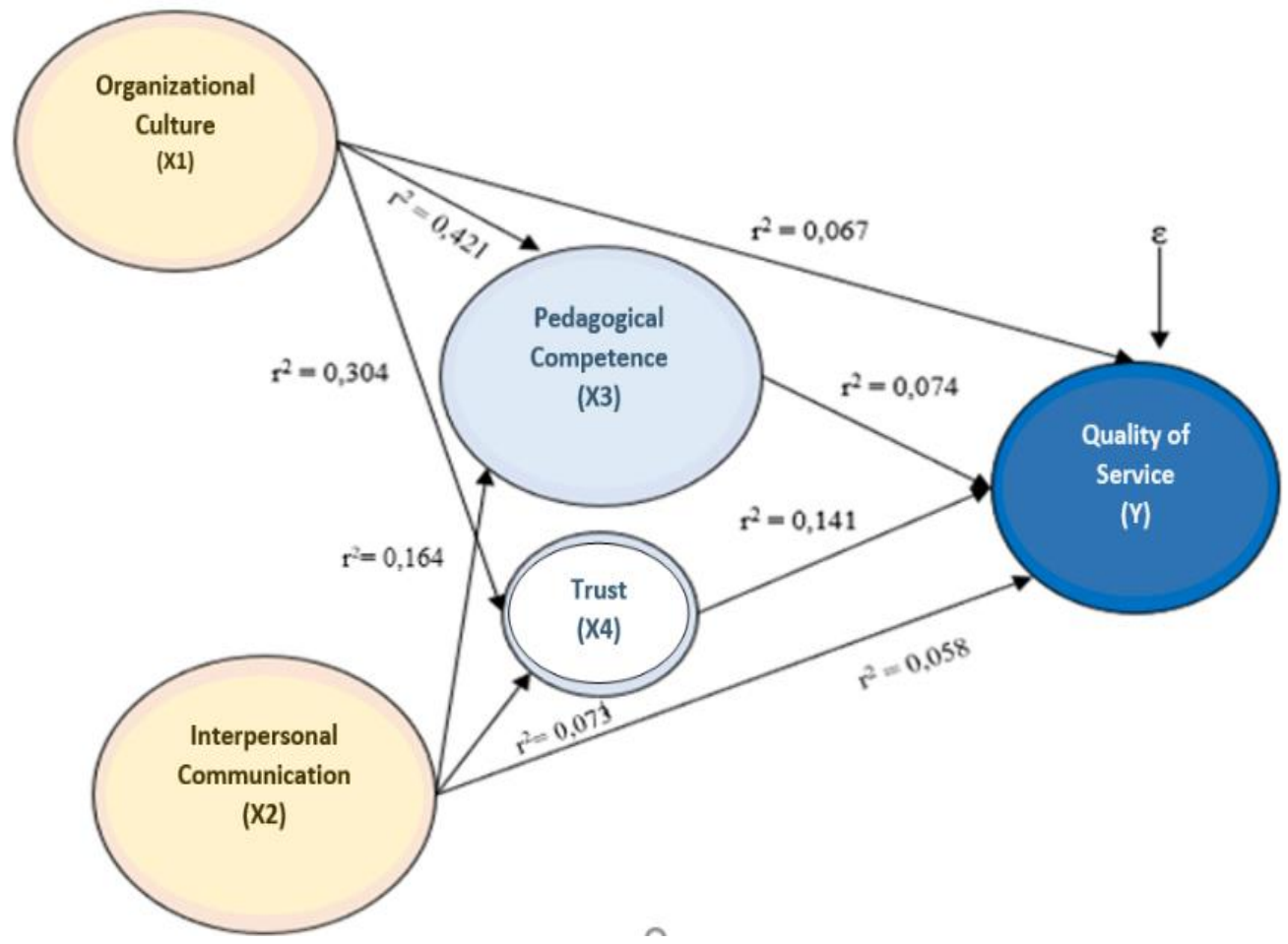

Figure 8. Path analysis of interrelationships between research variables

Further weighting for priority in building the quality of service that can be observed in the following table below. 
Improving the Quality of Service through Strengthening Organizational Culture, Interpersonal Communication, Pedagogical Competence and Trust (Empirical Research Using Pathway Analysis and Sitorem in Lecturers Indonesia Defence University)

Table 13. Priority of Variable Improvement in Improving Service Quality

\begin{tabular}{|c|c|c|}
\hline Variable & Sub-Variable Improvement Efforts & $\begin{array}{l}\text { Priority } \\
\text { order }\end{array}$ \\
\hline \multirow{5}{*}{ Trust $\left(\mathrm{X}_{4}\right)$} & Organizational competence & 1 \\
\hline & Recognition of the organization & 2 \\
\hline & Openness of the organization & 3 \\
\hline & Integrity of the organization & 4 \\
\hline & Organizational concern & 5 \\
\hline \multirow{6}{*}{$\begin{array}{l}\text { Pedagogical } \\
\text { Competence (x3) }\end{array}$} & Mastery of learning theories and educational principles & 6 \\
\hline & Assessment and evaluation & 7 \\
\hline & Ability to master the characteristics of learners & 8 \\
\hline & Ability to develop curriculum & 9 \\
\hline & Ability to create educational learning activities & 10 \\
\hline & Ability to develop the potential of learners & 11 \\
\hline \multirow{7}{*}{$\begin{array}{l}\text { Organizational } \\
\text { Culture }(\mathrm{x} 1)\end{array}$} & future orientation & 12 \\
\hline & uncertainty avoidance & 13 \\
\hline & power distance & 14 \\
\hline & assertiveness & 15 \\
\hline & humane orientation & 16 \\
\hline & institutional collectivism & 17 \\
\hline & performance orientation & 18 \\
\hline \multirow{5}{*}{$\begin{array}{l}\text { Interpersonal } \\
\text { Communication } \\
(\mathrm{x} 2)\end{array}$} & Feedback & 19 \\
\hline & Word selection & 20 \\
\hline & Active listening & 21 \\
\hline & Empathy & 22 \\
\hline & Emotional management & 23 \\
\hline
\end{tabular}

From the results of the priority of increasing these sub-variables, a strategy is expected to be formed that ensures the establishment of a quality of service at the Defense University. The quality of lecturer service in this research assumption will be closely related to providing the right quality of education for student development in accordance with their interests and talents, it is part of integral to measurable and controlled education management.

\section{CONCLUSIONS}

Broadly speaking, this research is carried out so as to produce four main independent variables which are further separated on endogenous variables (pedagogical competence and trust) and exogenous (organizational culture and interpersonal communication) to be tested and strived to understand the quality of education. These variables are further deepened to allow for a more in-depth analysis of the connectedness between independent variables. The details of this study can be summed up as follows:

1. There is the most significant positive relationship between trust (X4) and quality of service, a significant positive relationship obtained also when linking efforts to the following variables in a row; Pedagogical Competence (X3), Organizational Culture (X1), and Interpersonal Communication (X2). When the four variables are jointly analyzed the relationship to the quality of service also provides a significant and positive relationship picture of service quality, where $34 \%$ of the variation in service quality is influenced by these four factors. Positive connectedness is obtained between organizational culture with trust, as well as interpersonal communication with trust, while endogenous variables in the form of pedagogical competence are negatively related to organizational culture and interpersonal communication.

2. In this study found various other variables that have a strong enough dominance in revealing the development of service quality. Factors in the form of organizational competence, mastery of learning theories and principles of education, future orientation, communication with feedback. Organizational competence in the context of trust which is assumed to be a belief in the potential advantages possessed by the organization, characterized in previous behavior when facing problem situations / conditions. Lecturer performance that is seen directly in students also has a very significant impact on improving the quality of lecturer services. Unhan lecturer's mastery of learning theories and educational principles related to the adjustment of various learning methods that can be adaptive to the characteristics of learners so as to motivate them in carrying out an educational process has also had an impact on the quality of service. 
3. SITOREM analysis allows for the most dominant factors inherent in a managerial problem, can be answered quickly and precisely. The issue of the quality of lecturer services at UNHAN as a measuring tool to improve the quality of education, can be deepened in factors that are specific and specific to the condition and background and ability of the institution. Quality of service that tends to be broad and allows distortions of various factors that are not directly and significantly related can be separated through the SITOREM approach, especially during qualitative analysis involving key sources and supporters in a research locus. Furthermore, quantitative analysis allows the certainty value of the strength of the relationship between the measured factors, so that a study can be carried out effectively and efficiently.

4. This study produced four factors that are other variables that need to be studied in depth, but the six factors are still an integral part in four main variables, namely organizational culture, interpersonal communication, pedagogical competence and trust. The four factors in question are organizational competence, mastery of learning theories and educational principles, future orientation, and communication with feedback. These factors showed a very significant association to service quality in the study. Thus it can be assumed that the four factors that are sub-variables can be the key to improving the quality of service especially in Unhan. However, the limitations of this study on variables and generalizations have not been strongly extended to a higher scope of theoretical studies, thus allowing for the development of research with more specific research objects in accordance with the findings of this study in other areas as well as wider scope.

\section{REFERENCES}

1) Alerasoul, S. A., Afeltra, G., Hakala, H., Minelli, E., \& Strozzi, F. (2021). Organisational learning, learning organisation, and learning orientation: An integrative review and framework. Human Resource Management Review. https://doi.org/10.1016/j.hrmr.2021.100854

2) Arief, R., Midhio, I. W., Risman, H., Anwar, S., \& Prakoso, L. Y. (2021). Makassar War in the Perspective of the Indonesian Total War. Journal of Social and Political Sciences, 4(2). https://doi.org/10.31014/aior.1991.04.02.291

3) Arto, R. S., Prakoso, L. Y., \& Sianturi, D. (2019). Strategi Pertahanan Laut Indonesia dalam Perspektif Maritim Menghadapi Globalisasi. Strategi Pertahanan Laut, 5(2), 65-86.

4) Badan Pusat Statistik. (2021). Berita Resmi Statistik: Indeks Pembangunan Manusia (IPM) Tahun 2020. BPS No.97/12/Th. XXIII, 15 Desember 2020. BPS.

5) Bandur, A. (2016). Penelitian Kualitatif: Metodologi, Desain, dan Teknik Analisis. Mitra Wacana Media.

6) Bjekić, D., Vučetić, M., \& Zlatić, L. (2014). Teacher Work Motivation Context of In-service Education Changes. Procedia - Social and Behavioral Sciences, 116, 557-562. https://doi.org/10.1016/j.sbspro.2014.01.257

7) Bui, H., \& Baruch, Y. (2010). Creating learning organizations: A systems perspective. Learning Organization, 17(3), 208227. https://doi.org/10.1108/09696471011034919

8) Colquitt, J. A., LePine, J. A., \& Wesson, M. J. (2009). Organizational behavior: Improving performance and commitment in the workplace. In -: Vol. (Issue). mc.

9) Conchie, S. M., Taylor, P. J., \& Charlton, A. (2011). Trust and distrust in safety leadership: Mirror reflections? Safety Science, 49(8-9), 1208-1214. https://doi.org/10.1016/j.ssci.2011.04.002

10) Creswell, J, W. (2008). Educational Research: Planning, Conducting, and Evaluating Quantitative and Qualitative Research. In Pearson Education. http://basu.nahad.ir/uploads/creswell.pdf\%0Ahttps://www.pearson.com/us/highereducation/product/Creswell-Educational-Research-Planning-Conducting-and-Evaluating-Quantitative-and-QualitativeResearch-3rd-Edition/9780136135500.html

11) Creswell, J. (2013). Qualitative, quantitative, and mixed methods approaches. In Research design. Sage publications. http://scholar.google.com/scholar?hl=en\&btnG=Search\&q=intitle:Research+design+-

+Qualitative,+Quantitative, +and+mixed+methods+approaches\#0

12) Di Fabio, A. (2017). Positive healthy organizations: Promoting well-being, meaningfulness, and sustainability in organizations. In Frontiers in Psychology (Vol. 8, Issue NOV). https://doi.org/10.3389/fpsyg.2017.01938

13) Dipua, A., Hermawa, R., Puspitawati, D., Harahap, N., Nurdiansyah, D. R., \& Prakoso, L. Y. (2020). An Analysis Of The South China Sea Conflict: Indonesia's Perspectives, Contexts And Recommendations. PalArch's Journal of Archaeology of Egypt/Egyptology, 17(4), 976-990.

14) Hadi, S. (2010). Metodologi Riset. Pustaka Pelajar.

15) Harris, A., Prakoso, L. Y., \& Sianturi, D. (2019). Strategi Pertahanan Laut dalam Rangka Ancaman Keamanan di Alur Laut Kepulauan Indonesia II. Journal of Social and Political Sciences, Vol.4 No.2 (2021), 5(1), 15-30. https://papers.ssrn.com/sol3/papers.cfm?abstract_id=3838453

16) Hermawan, T., Prakoso, L. Y., \& Sianturi, D. (2020). Strategi Pertahanan Laut dalam Analisa Dampak dan Upaya Pemerintah Mengamankan ALur Laut Kepulauan Indonesia. Strategi Pertahanan Laut, 6(3), 273-296. 
17) Junaidi, M. E., \& Prakoso, L. Y. (2021). Pancasila as the Basis for Indonesia's Universal Defense. Journal of Social and Political Sciences, 4(2). https://doi.org/10.31014/aior.1991.04.02.283

18) Kusuma, A. W., Prakoso, L. Y., \& Sianturi, D. (2019). Sinergitas Komando Armada I dan Badan Keamanan Laut Republik Indonesia dalam Strategi Pertahanan Laut Guna Memberantas Kejahatan Lintas Negara di Selat Malaka. Strategi Pertahanan Laut, 5(2), 51-64.

19) Lebo, D., Pramono, B., Prakoso, L. Y., Risman, H., \& Suhirwan, S. (2021). The Total War Strategy through Optimizing the Understanding of Pancasila Values in the Millenial Era. Journal of Social and Political Sciences, 4(2). https://doi.org/10.31014/aior.1991.04.02.273

20) Lukman Yudho Prakoso, Suhirwan, Kasih Prihantoro, Budi Pramono, Rianto, A. I. S. (2021a). BAHAN AJAR KEBIJAKAN PERTAHANAN LAUT (M. I. Setiadi (ed.)). UNHAN PRESS.

21) Lukman Yudho Prakoso, Suhirwan, Kasih Prihantoro, Budi Pramono, Rianto, A. I. S. (2021b). BAHAN AJAR SEJARAH PERANG (M. IKMAL SETIADI; SERI DEPY SUGIYANI (ed.)). UNHAN PRESS.

22) Madrohim, M., \& Prakoso, L. Y. (2021). The Total War Strategy Through the Improvement of the Role of National Shipyard in Supporting Main Weapon System of Indonesian Navy. Journal of Social and Political Sciences, 4(1). https://doi.org/10.31014/aior.1991.04.01.245

23) Martdupanus Manik, J., Fakultas Strategi Pertahanan, S., Yudho Prakoso, L., \& Sabrina Manik, A. (2019). Seminar Series in Humanities and Social Sciences: POST CONFLICT RESOLUTION OF THE 2019 PRESIDENTIAL ELECTION.

24) McShane, L. S., \& Von Glinow, M. (2018). Organizational behavior, fifth edition. McGraw-Hil.

25) Narindra, K., Sudibyo, \& Prakoso, L. (2021). Optimazation of the Diplomatic Strategy Through Cross-Culture Understanding for the Garuda Contingent in Naqoura South Lebanon. 16(2), 6363-6368.

26) Nizar, A. A., Pramono, B., \& Gunawan, R. (2021). STRATEGI \& KAMPANYE MILITER PEMANTAPAN BELA NEGARA MENGHADAPI KNFLIK SOSIAL (S. kasih P. L. Y. P. Rianto (ed.)) (M. I. Setiadi (ed.)). CV. Aksara Global Akademia.

27) Prakoso, Lukman Yudho, Suhirwan, prihantoro, K., Legionosuko, T., Rianto, Salim, G., \& Yusriadi, Y. (2021). Analysis Public Policy Of Defence Strategy. Journal of Legal, Ethical and Regulatory Issues, 24(Special Issue 1), 1-9.

28) Prakoso, Lukman Yudo, Prihantoro, K., \& Suhirwan, S. (2021). Urgensi Tranformasi Networking dan Driver Force Kebijakan Pertahanan. In M. I. Setiadi (Ed.), CV. Aksara Global Akademia.

29) Prasojo, M., Prakoso, L. Y., Mansyah, A., Hendra, A., \& Bangun, E. (2021). Pancasila as the Foundation of Political Ethics in Indonesia, Case Study of the Struggle for the Chairman of a Political Party in Indonesia. Journal of Social and Political Sciences, 4(2). https://doi.org/10.31014/aior.1991.04.02.280

30) Prihantoro, K., Prakoso, L. Y., Suhirwan, S., \& Kusmiati, M. (2021). Metode SWOT AHP dalam Merencanakan Strategi Pertahanan. In CV. Aksara Global Akademia. CV Aksara Global Akademia.

31) Salim, G., Indarjo, A., Zein, M., Yudho Prakoso, L., Suhirwan, Achmad Daengs, G. S., Rukisah, \& Bija, S. (2020). Analysis of allometric growth and condition index of tiger shrimp (Penaeus monodon) in Juata Laut Waters and Fishpond, Tarakan (Indonesia). IOP Conference Series: Earth and Environmental Science, 564(1). https://doi.org/10.1088/1755$1315 / 564 / 1 / 012010$

32) Sartono, Prakoso, L. Y., \& Sianturi, D. (2020). Impresi dan Otoritas Pemerintah dalam Mengamankan Alur Laut Kepulauan Indonesia (ALKI). Strategi Pertahanan Laut, 6(3), 231-256.

33) Scales, A. N., \& Quincy Brown, H. (2020). The effects of organizational commitment and harmonious passion on voluntary turnover among social workers: A mixed methods study. Children and Youth Services Review, 110. https://doi.org/10.1016/j.childyouth.2020.104782

34) Scrima, F., Di Stefano, G., Guarnaccia, C., \& Lorito, L. (2015). The impact of adult attachment style on organizational commitment and adult attachment in the workplace. Personality and Individual Differences, 86, 432-437. https://doi.org/10.1016/j.paid.2015.07.013

35) Shen, J., \& Tang, C. (2018). How does training improve customer service quality? The roles of transfer of training and job satisfaction. European Management Journal, 36(6), 708-716. https://doi.org/10.1016/j.emj.2018.02.002

36) Snyder, C. A. (1999). Contemporary Security and Strategy. In Contemporary Security and Strategy. Palgrave Macmillan. https://doi.org/10.1007/978-1-349-27359-1_1

37) Suhirwan, Lukman Yudho Prakoso, A. G. D. (2021). National Defense Policy by Strengthening Defense Strategy: Study of the Development of a Naval Air Base in Bengkulu. Italienisch, 11(2).

38) Supriyatno, M. (2014). Tentang ilmu pertahanan. Yayasan Pustaka Obor Indonesia, Jakarta. https://books.google.com/books/about/Tentang_Ilmu_Pertahanan.html?id=CaxxDAAAQBAJ

39) Vreÿ, F. (2012). Modern Strategy. In Scientia Militaria - South African Journal of Military Studies (Vol. 30, Issue 1). 
Improving the Quality of Service through Strengthening Organizational Culture, Interpersonal Communication, Pedagogical Competence and Trust (Empirical Research Using Pathway Analysis and Sitorem in Lecturers Indonesia Defence University)

Oxford University Press. https://doi.org/10.5787/30-1-169

40) Winarsunu, T. (2006). Statistik Dalam Penelitian Psikologi dan Pendidikan. In Jurnal Muhammadiyah Malang. Attribution - Non Commercial 4.0 International (CC BY-NC 4.0)

(https://creativecommons.org/licenses/by-nc/4.0/), which permits remixing, adapting and building upon the work for non-commercial use, provided the original work is properly cited. 